\title{
Effect of Modified Clay on the Growth Dynamics and Physio-Biochemical Response of Newly Hatched Larvae of the Marine Medaka (Oryzias melastigma)
}

\author{
Peipei Zhang ${ }^{1,2,3,4} \mathbb{D}^{\text {, Xiuxian Song }}{ }^{1,2,3,4, *}$, Yue Zhang ${ }^{1,2,3}$, Huihui Shen ${ }^{1,2,3,4}$, Xueyi Dong ${ }^{1,2,3}$, Jing Li 1,2,3 $^{\text {, }}$ \\ and Zhiming $\mathrm{Yu}^{1,2,3,4}$
}

1 Key Laboratory of Marine Ecology and Environmental Sciences, Institute of Oceanology, Chinese Academy of Sciences, Qingdao 266071, China; zhangpeipei@qdio.ac.cn (P.Z.); yzhang4@qnlm.ac (Y.Z.); shenhuihui@qdio.ac.cn (H.S.); 2018010004@mails.qust.edu.cn (X.D.); lijing@mju.edu.cn (J.L.); zyu@qdio.ac.cn (Z.Y.)

2 Laboratory of Marine Ecology and Environmental Science, Qingdao National Laboratory for Marine Science and Technology, Qingdao 266237, China

3 Center for Ocean Mega-Science, Chinese Academy of Sciences, Qingdao 266071, China

4 University of Chinese Academy of Sciences, Beijing 100049, China

* Correspondence: songxx@qdio.ac.cn

\section{check for} updates

Citation: Zhang, P.; Song, X.; Zhang, Y.; Shen, H.; Dong, X.; Li, J.; Yu, Z. Effect of Modified Clay on the Growth Dynamics and

Physio-Biochemical Response of Newly Hatched Larvae of the Marine Medaka (Oryzias melastigma). J. Mar. Sci. Eng. 2021, 9, 822. https://doi.org/10.3390/ jmse9080822

Academic Editor: Pedro Reis Costa

Received: 17 May 2021

Accepted: 7 July 2021

Published: 30 July 2021

Publisher's Note: MDPI stays neutral with regard to jurisdictional claims in published maps and institutional affiliations.

Copyright: (c) 2021 by the authors. Licensee MDPI, Basel, Switzerland. This article is an open access article distributed under the terms and conditions of the Creative Commons Attribution (CC BY) license (https:/ / creativecommons.org/licenses/by/ $4.0 /)$.

\begin{abstract}
An outbreak of harmful algal blooms (HABs) often leads to the death of fish and other marine organisms and causes serious losses to human economic activities. Modified clay (MC) technology is an effective way to control HABs. Although the material and preparation process are based on the premise of green and safety, the potential eco-environmental impacts of MC on nontarget organisms should still have to receive attention before field applications can occur. Therefore, the effects of one commonly used modified clay, polyaluminum chloride-modified clay (PAC-MC), on the survival, growth, and oxidative stress of the marine medaka (Oryzias melastigma) were studied. The toxicity test results showed that the 96-h median lethal concentration (96-h LC 50 ) of PAC-MC for newly hatched medaka larvae was $5.204 \mathrm{~g} / \mathrm{L}$, which was much higher than the concentration used on site $\left(4-10 \mathrm{t} / \mathrm{km}^{2}\right)$. Within the concentration range of PAC-MC used in this experiment $(\leq 2 \mathrm{~g} / \mathrm{L})$, the morphology, heart rate, growth, and aluminum content of larvae did not change with the increase in the modified clay concentration. Low concentrations of PAC-MC $(\leq 0.5 \mathrm{~g} / \mathrm{L})$ did not significantly affect catalase (CAT) activity, superoxide dismutase (SOD) activity, peroxidase (POD) activity, and the content of malondialdehyde (MDA), but higher concentrations of PAC-MC (such as $2 \mathrm{~g} / \mathrm{L}$ ) caused oxidative damage to the larvae and increased the antioxidant enzyme activity of the larvae. The present study revealed that under an effective dosage for treating harmful algal blooms on site, PAC-MC had no adverse effects on the survival, growth, oxidative stress, and aluminum content of the newly hatched marine medaka, which provides a scientific basis for the field application of modified clay.
\end{abstract}

Keywords: harmful algal bloom treatment; modified clay; marine medaka; marine toxicity tests

\section{Introduction}

Harmful algal blooms (HABs) have gradually evolved from a regional environmental problem to a global ecological disaster. The frequency, scale, distribution range, and species of HABs are all increasing or expanding. HABs lead to a large number of deaths of fish and other marine aquaculture organisms, resulting in more and more serious economic losses. For example, in 2016, a bloom of Pseudochattonella sp. broke out, and about $12 \%$ of Chilean salmon died, causing an economic loss of more than USD 800 million [1]. It is particularly important to find effective and environmentally friendly methods to control HABs.

Common HAB treatment methods include physical methods [2-5], chemical methods [6-8], and biological methods [9-12]. However, due to low efficiency, high cost, and 
uncontrollable ecological effects, the practical application of the above methods is limited. In the late 1970s, Japanese scholars used natural clay mineral to treat HABs in the coastal waters of Kagoshima [2,13]. Natural clay has the advantages of pollution-free and lowcost treatment, but low flocculation efficiency is the biggest bottleneck in its application process. For instance, in the treatment of Cochlodinium polykrikoides blooms in the coastal aquaculture areas of Korea, approximately 60,000 tons of loess (approximately $400 \mathrm{~g} / \mathrm{m}^{2}$ ) were used [14]. Zhiming Yu and his team proposed clay surface modification technologies and methods [15-18] and used modifiers combined with natural clays to overcome the problems related to the need for large amounts of material and low removal efficiency and reduce dosing requirement to $4-10 \mathrm{t} / \mathrm{km}^{2}$ [19]. Modified clay (MC) is widely used in the coastal waters of China. The MC flocculation method removes the algal cells from the water column through the flocculation between the clay particles and the algal cells and subsequently settles to the bottom of the water, so as to achieve the goal of effectively killing harmful algae and reducing the negative effect of HABs. Therefore, of prime consideration is the impact of clay addition on non-target organisms in the water column and the benthic environment.

A considerable amount of research has been conducted on the impact of MC on nontarget organisms. Filter-feeding or benthic shellfish are likely to be affected during the occurrence and treatment of HABs. The impact of different types of clay on shellfish has been reported. A previous study showed that the actual application concentration of ball clay did not have a significant impact on Perna viridis Linnaeus [20]. Under appropriate dosages, different types of modified clay have no adverse effects on various marine shellfish such as Patinopecten yessoensis, Mercenaria mercenaria juveniles, Crassostrea gigas juveniles, and abalones [21-24]. Compared to shellfish, fish are more mobile and can avoid risks quickly, and they should be relatively less harmed by HABs. However, due to the increase in the scale of offshore fish farming, when HABs break out at a large scale, a large number of fish still die, causing huge economic losses. Therefore, it is urgent to determine the impact of modified clay on fish, especially marine model fish species. This is of great significance for investigating the impact of $\mathrm{MC}$ for the treatment of HABs on fish and for comprehensively assessing the ecological effects of MC.

The marine medaka (Oryzias melastigma) is an important model for marine ecotoxicology research [25]. It possesses characteristics such as a small size, easy cultivation, short generation time, small genome, and high adaptability to broad ranges of temperature and salinity. It has been investigated to assess the ecological risk related to a variety of marine pollutants. The early developmental stage juveniles are much more sensitive to external stimuli than the late juveniles and adult fish. Therefore, this study used newly hatched larvae of the marine model fish species marine medaka (Oryzias melastigma) as the experimental object to explore the effects of PAC-MC on their survival, morphology, oxidative stress, and other aspects, in order to provide a sound scientific basis for the application of modified clay to control harmful algal blooms in marine aquaculture areas.

\section{Materials and Methods}

\subsection{Fish Culture and Modified Clay Preparation}

The adult marine medaka used in the experiment were cultured in $0.45 \mu \mathrm{m}$ filtered seawater. The initial $\mathrm{pH}$ of the seawater was 7.9, salinity was $32 \pm 1$, water temperature was maintained at $26 \pm 1{ }^{\circ} \mathrm{C}$, and the constant photoperiod was $12 \mathrm{~h}$ light: $12 \mathrm{~h}$ dark. Through continuous aeration, the dissolved oxygen in the water was always greater than $5 \mathrm{mg} / \mathrm{L}$. Marine medaka were fed Artemia salina twice a day. The eggs were collected from adult fish and hatched, and healthy and active newly hatched larvae (incubation time $<24 \mathrm{~h}$ ) were selected for experiments.

The experimental clay was kaolin deposit of Changle Town, Hepu County, Beihai, Guangxi, China, which was modified according to the method of Yu et al. [16]. The mineral composition of the experimental kaolin is shown in Figure S1 and Tables S1 and S2. The modifier was PAC (Tianjin Guangfu Fine Chemicals, Tianjin, China) at a ratio of 1:5 (w/w), 
which is the ratio that is typically used in the field [21]. A suspension containing the MC at $25 \mathrm{~g} / \mathrm{L}(w / v)$ was prepared with seawater and sprayed into the experimental system immediately after preparation.

\subsection{Experimental Design}

The concentration sequence of PAC-MC 0 (control group), 0.2, 0.5, 2, 3, 4, 5, 6, and $7 \mathrm{~g} / \mathrm{L}$ was set to conduct a 96-h acute toxicity test on the newly hatched larvae of marine medaka. The newly hatched larvae were randomly divided into eight groups, with 10 fish in each group and three replicates per treatment. They were transferred into a $500 \mathrm{~mL}$ beaker for follow-up experiments without changing water or feeding. After the larvae were grouped, PAC-MC was sprayed into the experimental system, and the spraying time was defined as 0 . At $0.5,1,3,6,12,24,48,72$, and $96 \mathrm{~h}$ after the experiment, the $\mathrm{pH}$, turbidity, dissolved aluminum, and other environmental parameters of the experimental system were determined, and the survival of the newly hatched larvae was observed. When all the larvae died or the 96-h experiment was over, the external morphology of the larvae was observed and photographed under an optical microscope. No response to touching the tail of larvae with a glass rod was regarded as a sign of larval death.

A PAC-MC concentration series of $0,0.2,0.5$, and $2 \mathrm{~g} / \mathrm{L}$ was set. The newly hatched larvae were randomly divided into four groups, with 10 fish in each group and 12 replicates per treatment. After the larvae were grouped, PAC-MC was sprayed into the experimental system, and the spraying time was defined as 0 . At $0.5,1,3,6,12,24,48,72$, and $96 \mathrm{~h}$, the heart rate of the larvae was measured. At $0,3,6,12,24,48,72$, and $96 \mathrm{~h}$, five larvae in each group were frozen in liquid nitrogen and stored in a refrigerator at $-80^{\circ} \mathrm{C}$ to determine the larvae's antioxidant system-related enzyme activity indicators. The antioxidant systemrelated enzymes include superoxide dismutase (SOD), catalase (CAT), malondialdehyde (MDA), peroxidase (POD), and total protein. Six hours after the addition of the modified clay, samples were collected to determine the content of reactive oxygen species (ROS) in the larvae. At the end of the experiment, the total length of the larvae and their aluminum content were measured.

\subsection{Measurement of Basic Parameters}

\subsubsection{Environmental Parameter Measurement}

PAC-MC is made by adding PAC on the basis of kaolin. Adding it to a seawater system will cause changes in parameters such as $\mathrm{pH}$, turbidity, and total dissolved aluminum content, which will affect the survival and physiological metabolism of larvae. The metabolism of the larvae will affect the nutrients in the seawater, and the excessive accumulation of $\mathrm{NH}_{4}{ }^{+}-\mathrm{N}$ and $\mathrm{NO}_{2}{ }^{-}-\mathrm{N}$ will also cause harm to the larvae. Therefore, the above water quality parameters were measured in the experiment.

The particle size distribution of the clay before and after PAC modification was measured by using a laser particle size analyzer (Mastersizer A3000, Malvern, UK). The pH was measured by a pH meter (S400 Seven Excellence, Mettler Toledo, Zurich, Switzerland) with an accuracy of \pm 0.002 . Turbidity was measured by a turbidimeter (WZS-200, Anting, Shanghai, China), and total dissolved aluminum in water was measured with the Al-Ferron method [26,27]. Thirty-milliliter seawater samples were filtered by a GF/F (Whatman ${ }^{\mathrm{TM}}$ glass microfiber filters, diameter $47 \mathrm{~mm}$ ) membrane and then analyzed using a continuousflow analyzer (SKALAR Flow Analyzer, Skalar Ltd., Breda, The Netherlands).

\subsubsection{Oxidative Stress Indicators}

Many pollutants may produce toxicity associated with oxidative stress. Reactive oxygen species (ROS) can cause enzyme inactivation, lipid peroxidation (LPOX), DNA damage, and ultimately, cell death [28]. Antioxidant enzymes are one of the defensive systems that inhibit the formation of oxyradical, in which SOD plays a key antioxidant role, and it exists in almost all aerobic organisms examined [29]. CAT can promote the removal of hydrogen peroxide and metabolize hydrogen peroxide into molecular oxygen and water. 
Peroxidases (POD) are enzymes that reduce a variety of peroxides to their corresponding alcohols [30]. MDA is a commonly used parameter that reflects lipid peroxidation.

When determining parameters such as antioxidant enzymes, the larvae were processed into a $10 \%$ tissue homogenate and centrifuged at $3000 \times \mathrm{g}$ for $15 \mathrm{~min}$ to collect the supernatant. Superoxide dismutase (SOD), catalase (CAT), malondialdehyde (MDA), and peroxidase (POD) were determined through the corresponding kits of the Nanjing Jiancheng Bioengineering Institute. The protein concentration was determined by a Solarbio Bradford kit. ROS were detected using the fluorescent probe DCFH-DA staining method, and the fluorescence microscope (Olympus IX71+DP73+U-RFL-T) is used to take pictures. When taking pictures, try to ensure that the parameters of each picture are the same, and then use software ImageJ to detect the average fluorescence intensity of the fluorescence microscope pictures for subsequent comparison.

\subsubsection{Aluminum Content of the Fish}

Randomly take 60 larvae from each treatment and divide them into three groups with 20 fish in each group. After 20 larvae in each group were ground into tissue homogenate, the aluminum content was determined by inductively coupled plasma mass spectrometry (iCAP QC ICP-MS, Thermo Fisher, Waltham, MA, USA).

\subsubsection{Microscope Observation}

The larvae were removed from the experimental system and placed into an appropriate amount of seawater to keep them alive without swimming quickly. They were placed under an optical microscope (Olympus IX71), and the number of heartbeats of the larvae within $60 \mathrm{~s}$ was counted to calculate the heart rate.

The larvae were removed from each group and frozen in ice water for anesthesia, placed under an optical microscope (Olympus IX71+DP73) to observe the external shape of the larvae, and photographed. In the experiment, we mainly observed whether the fins were intact, whether the trunk was deformed, whether there was damage to the body surface, and whether particles were attached.

Scanning electron microscope (S-3400NSEM, Hitachi, Japan) was used to observe the changes in clay surface morphology before and after PAC modification. Disperse $1 \mathrm{~g}$ of PAC-MC and $1 \mathrm{~g}$ of kaolin in $20 \mathrm{~mL}$ ultrapure water, respectively. After shaking up, place the suspension in liquid nitrogen to quickly freeze, and freeze-dry at $-52{ }^{\circ} \mathrm{C}, 20 \mathrm{~Pa}$. The freeze-dried sample was sprayed with gold and then observed by SEM.

\subsection{Statistical Analysis}

The main data analysis methods of this study were one-way ANOVA and two-way ANOVA. A significance level of $\alpha=0.05$ was established; $p>0.05$ indicated no significant difference. The data were analyzed and processed by Statistical Product and Service Solutions (SPSS) (IBM Corp. Released 2013. IBM SPSS Statistics for Windows, Version 22.0. Armonk, NY, USA: IBM Corp.), and the figures were drawn using Origin Pro 2016.

\section{Results}

3.1. Growth Indicators of Marine Medaka

\subsubsection{Survival}

The survival of larvae in each group after the addition of PAC-MC is shown in Table 1. No larvae died in the 0 (control group), $0.2,0.5$, and $2 \mathrm{~g} / \mathrm{L}$ groups within $96 \mathrm{~h}$. By calculation, the $48-\mathrm{h} \mathrm{LC} 50$ and $96-\mathrm{h} \mathrm{LC} 50$ of PAC-MC applied to marine medaka larvae were $5.449 \mathrm{~g} / \mathrm{L}$ and $5.204 \mathrm{~g} / \mathrm{L}$, respectively. The safe concentration (SC, calculated according to the formula SC $=0.3 \times 48-\mathrm{h} \mathrm{LC}_{50} /\left(24 \mathrm{~h} \mathrm{LC}_{50} / 48-\mathrm{h} \mathrm{LC}_{50}\right)^{2}$ [31] $)$ was $1.94 \mathrm{~g} / \mathrm{L}$. When the concentration of PAC-MC increased further, the larvae began to die. The greater the concentration of PAC-MC, the higher the mortality of larvae at the same time point, and the earlier the larval death occurred. The $7 \mathrm{~g} / \mathrm{L}$ group died at $3 \mathrm{~h}$, and all died at $48 \mathrm{~h}$. 
Table 1. Effect of PAC-MC on the survival rate of marine medaka larvae.

\begin{tabular}{ccccc}
\hline $\begin{array}{c}\text { Concentration of } \\
\text { PAC-MC (g/L) }\end{array}$ & $\begin{array}{c}\text { Survival Rate at } \mathbf{3} \mathbf{h} \\
\mathbf{( \% )}\end{array}$ & $\begin{array}{c}\text { Survival Rate at } \mathbf{1 2} \mathbf{h} \\
\mathbf{( \% )}\end{array}$ & $\begin{array}{c}\text { Survival Rate at } \mathbf{4 8} \mathbf{h} \\
\mathbf{( \% )}\end{array}$ & $\begin{array}{c}\text { Survival Rate at } \mathbf{9 6} \mathbf{h} \\
\mathbf{( \% )}\end{array}$ \\
\hline 0 & $100 \pm 0$ & $100 \pm 0$ & $100 \pm 0$ & $100 \pm 0$ \\
0.2 & $100 \pm 0$ & $100 \pm 0$ & $100 \pm 0$ & $100 \pm 0$ \\
0.5 & $100 \pm 0$ & $100 \pm 0$ & $100 \pm 0$ & $100 \pm 0$ \\
2 & $100 \pm 0$ & $100 \pm 0$ & $96.3 \pm 6.4$ & $100 \pm 0$ \\
3 & $100 \pm 0$ & $100 \pm 0$ & $93.3 \pm 11.6$ & $84.3 \pm 13.7$ \\
4 & $100 \pm 0$ & $100 \pm 0$ & $88.9 \pm 9.6$ & $83.3 \pm 5.8$ \\
5 & $100 \pm 0$ & $88.9 \pm 9.6$ & $11.1 \pm 9.6$ & $11.1 \pm 9.6$ \\
7 & $100 \pm 0$ & $64.4 \pm 17.1$ & $0 \pm 0$ & $0 \pm 0$ \\
\hline
\end{tabular}

\subsubsection{Heart Rate and Total Length of the Larvae}

The heart rate of the larvae in the control group and 0.2, 0.5, and $2 \mathrm{~g} / \mathrm{L}$ PAC-MC groups was measured (Figure 1). The results showed that as the larvae grew, their heart rate increased with time. The heart rate increased from 128 beats $/ \mathrm{min}$ at $3 \mathrm{~h}$ to 176 beats $/ \mathrm{min}$ at $96 \mathrm{~h}$. The heart rates of larvae in the three PAC-MC concentration groups at each time point were not significantly different from those of the control group $(p>0.05)$, which showed that the used concentration range of clay did not affect the heart rate of newly hatched larvae.

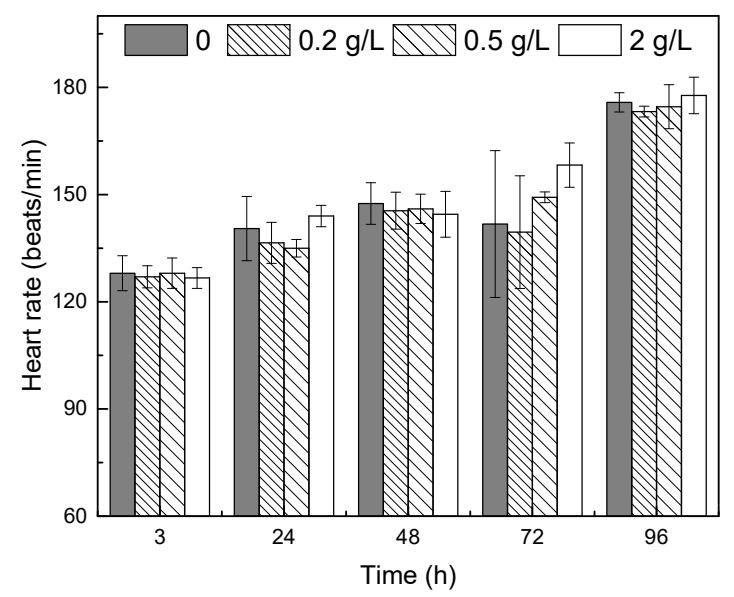

Figure 1. The effect of PAC-MC on the heart rate of newly hatched marine medaka. $\mathrm{N}=3$, mean \pm SD; ANOVA, Tukey.

After the 96-h experiment, the total length of the newly hatched larvae was measured. The total lengths of the larvae in the $0,0.2,0.5$, and $2 \mathrm{~g} / \mathrm{L}$ groups were $3.41 \pm 0.04 \mathrm{~mm}$, $3.29 \pm 0.12 \mathrm{~mm}, 3.31 \pm 0.25 \mathrm{~mm}$, and $3.52 \pm 0.18 \mathrm{~mm}$, respectively. The statistical analysis results showed that there was no significant difference in larval body length $(p>0.05)$ between the modified clay groups and the control group (Figure S2).

\subsubsection{Morphological Observation}

Three hours after the modified clay was sprayed, the flocculation process was basically completed, and most of the clay particles settled to the bottom. The external morphology of the newly hatched larvae was observed and photographed under a microscope at $6 \mathrm{~h}$ and $96 \mathrm{~h}$ (Figure 2). The external morphology of the larvae at $6 \mathrm{~h}$ showed that the 0.2, 0.5, and $2 \mathrm{~g} / \mathrm{L}$ PAC-MC did not cause damage to the morphology of the larvae within $6 \mathrm{~h}$. However, in the $7 \mathrm{~g} / \mathrm{L}$ PAC-MC group, some larvae died rapidly within $3 \mathrm{~h}$. Some larvae were still alive after $3 \mathrm{~h}$, but there were obvious clay particles attached to the bodies of the fish. The larvae were deformed, and the fins were severely damaged. All the larvae in this group died within $48 \mathrm{~h}$. At the end of the toxicity experiment (96 h), compared with the 
control group, the shape of the larvae in the $0.2 \mathrm{~g} / \mathrm{L}$ and $0.5 \mathrm{~g} / \mathrm{L}$ PAC-MC groups had no obvious damage, but in the $2 \mathrm{~g} / \mathrm{L}$ modified clay group, although the fins remained intact, there were small amounts of clay particles attached to the surface of the anal fin.
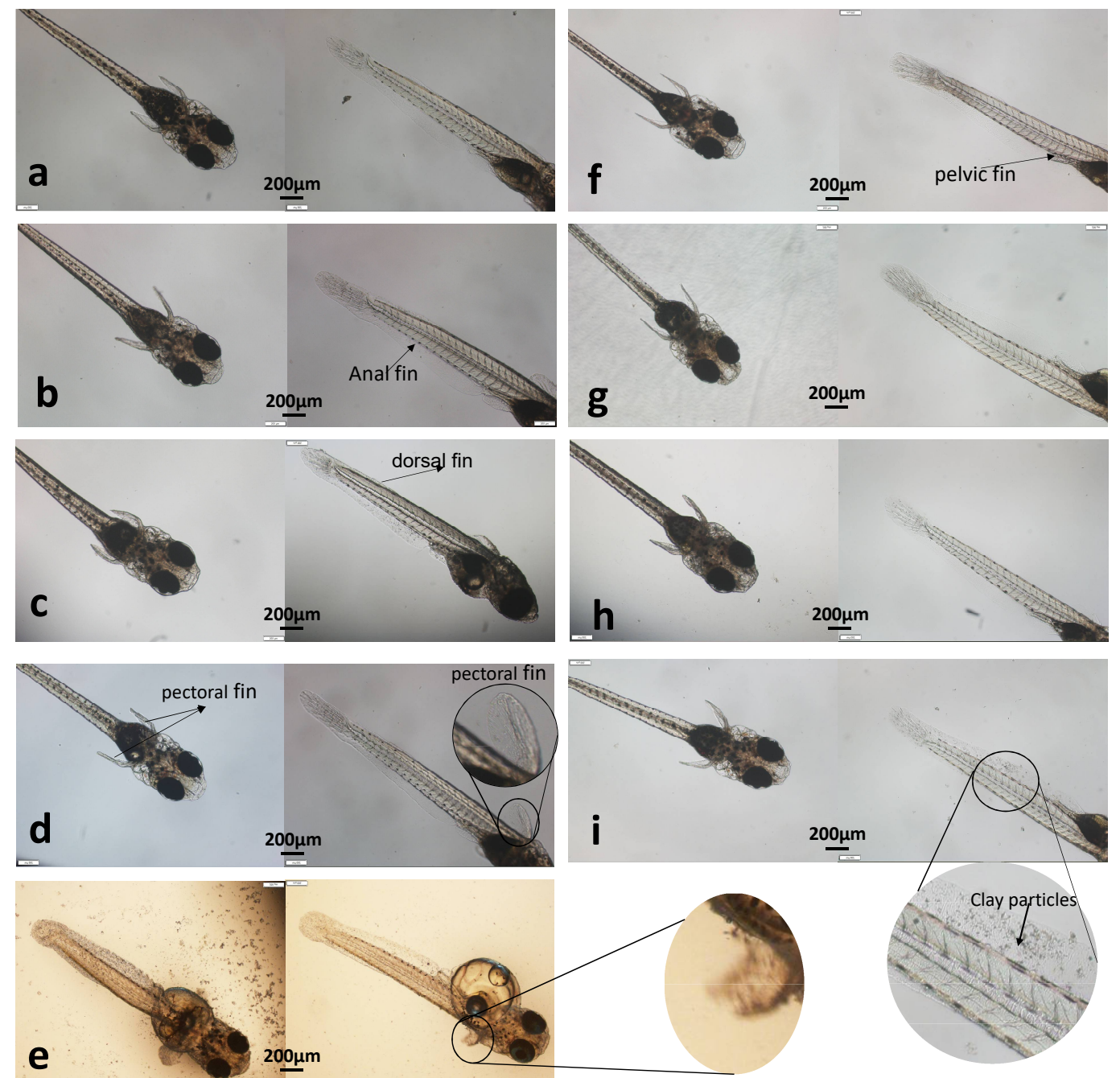

Figure 2. The external morphology of the newly hatched larvae of medaka at different time points. (a-e) Morphology of the larvae in the control, $0.2,0.5,2$, and $7 \mathrm{~g} / \mathrm{L}$ PAC-MC groups after the addition of modified clay for $6 \mathrm{~h}$. (A-D) Morphology of the larvae in the control, $0.2,0.5$, and $2 \mathrm{~g} / \mathrm{L}$ PAC-MC groups after the addition of modified clay for $96 \mathrm{~h}$.

\subsection{Oxidative Stress Indicators}

Compared with the control group, there was no significant difference in the area of ROS in the $0.2 \mathrm{~g} / \mathrm{L}$ and $0.5 \mathrm{~g} / \mathrm{L}$ PAC-MC groups, but those in the $2 \mathrm{~g} / \mathrm{L}$ PAC-MC group increased significantly (Figure 3). In the experiment, the images of the ROS fluorescence intensity of each treatment group (Figure S3) were measured and analyzed. It was found that compared with the control group, only the fluorescence intensity of the $2 \mathrm{~g} / \mathrm{L}$ group had a significant difference $(p<0.05)$ (Tables S3 and S4). 

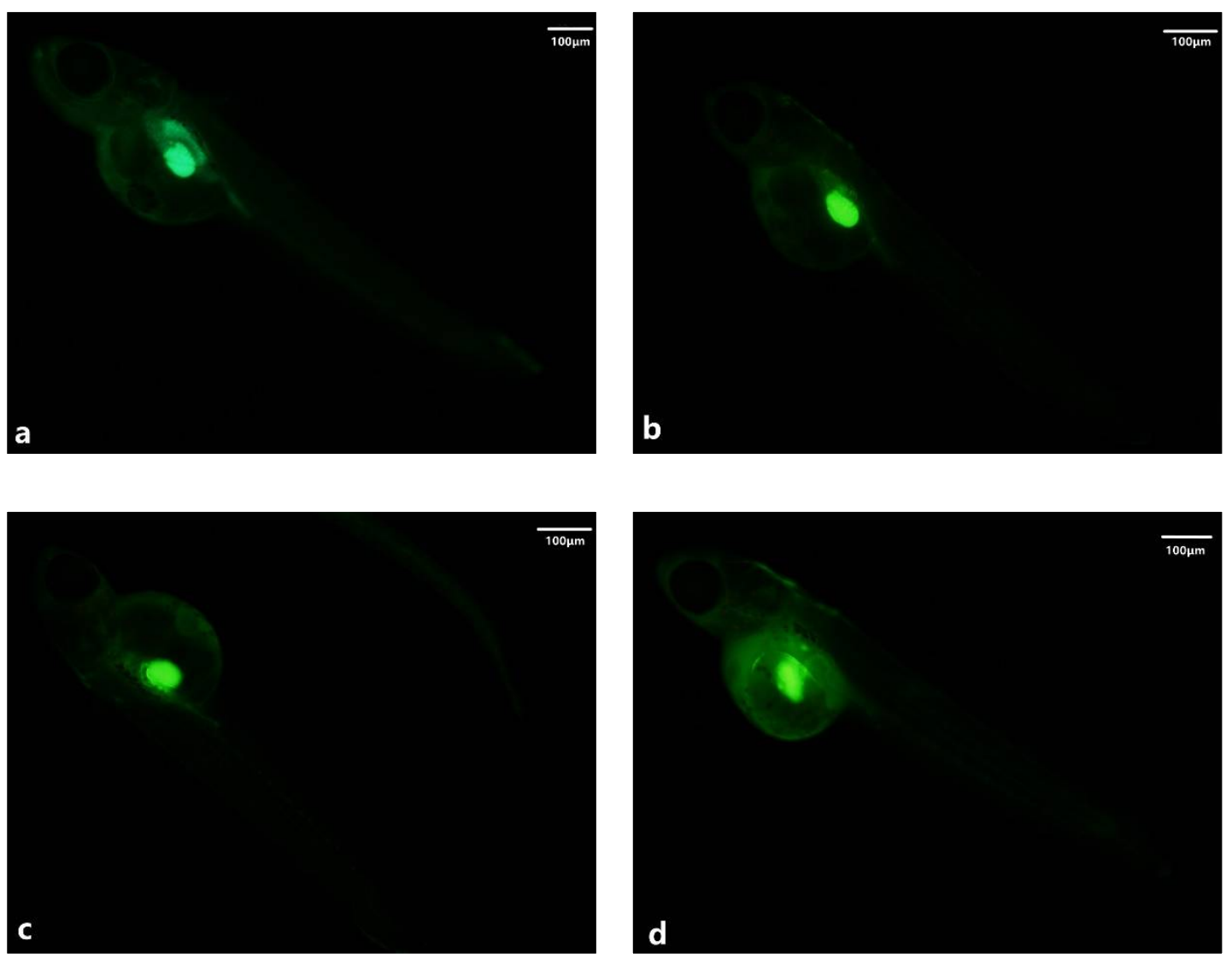

Figure 3. ROS content in newly hatched larvae of medaka. (a-d) Level of ROS in larvae after the addition of $0,0.2,0.5$, and $2 \mathrm{~g} / \mathrm{L}$ PAC-MC, respectively, for $6 \mathrm{~h}$.

In addition to ROS, the content of the lipid peroxidation product MDA and the changes in the activities of typical antioxidant enzymes, i.e., SOD, CAT, and POD, were tracked. The MDA content and SOD, CAT, and POD activities under different modified clay concentrations were significantly different, while the different lengths of time had a significant impact only on the CAT and POD activities. In addition, no significant interaction between time and modified clay was observed for all indicators (Table 2). As the MC concentration increases, the oxidative stress response of the marine medaka increases. Compared with the control group, the $0.2 \mathrm{~g} / \mathrm{L}$ and $0.5 \mathrm{~g} / \mathrm{L}$ PAC-MC did not cause significant oxidative damage within $96 \mathrm{~h}$, and there were no significant differences in the lipid peroxidation index (MDA content) and the SOD, CAT, and POD enzyme activities $(p>0.05)$. However, compared with the control group, the MDA content of the $2 \mathrm{~g} / \mathrm{L}$ PAC-MC group increased significantly at all sampling points, the SOD enzyme activity was significantly higher than that in the control group after $3 \mathrm{~h}$, and the CAT enzyme activity increased significantly at $6 \mathrm{~h}$. At $12 \mathrm{~h}$, the activity of POD was observed to increase greatly (Figure 4).

Table 2. Summary of 2-way analysis of variance testing the effects of time and modified clay on MDA, SOD, CAT, and POD in marine medaka.

\begin{tabular}{ccccccccccc}
\hline & & \multicolumn{2}{c}{ MDA } & \multicolumn{2}{c}{ SOD } & \multicolumn{1}{c}{ CAT } & \multicolumn{2}{c}{ POD } \\
\hline Source & $\mathbf{d f}$ & $\mathbf{F}$ & $\mathbf{P}$ & $\mathbf{F}$ & $\mathbf{P}$ & $\mathbf{F}$ & $\mathbf{P}$ & $\mathbf{F}$ & $\mathbf{P}$ \\
\hline Time & 6 & 1.523 & 0.187 & 1.429 & 0.220 & 5.378 & 0.000 & 2.960 & 0.014 \\
MC & 3 & 30.996 & 0.000 & 31.861 & 0.000 & 32.727 & 0.000 & 25.704 & 0.000 \\
Time $\times$ & 18 & 0.479 & 0.957 & 0.493 & 0.951 & 1.367 & 0.185 & 0.903 & 0.578 \\
MC & & & & & & & & & & \\
\hline
\end{tabular}



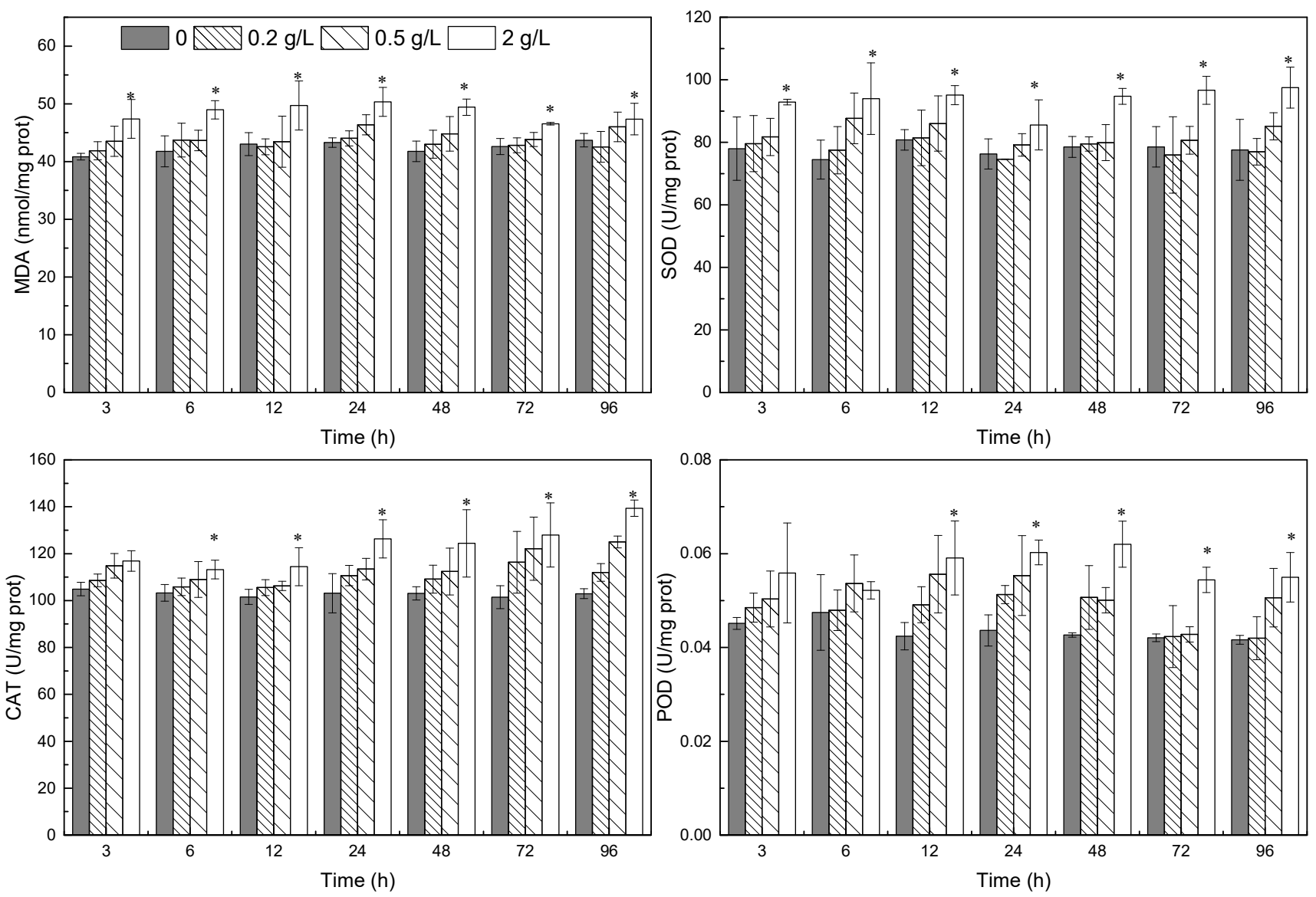

Figure 4. Changes in the antioxidant system parameters of newly hatched larvae over time, mean \pm SD; ANOVA, Tukey; * significant difference compared with control at each time point at $p<0.05$.

\subsection{Environmental Parameters}

The changes in $\mathrm{pH}$, turbidity, and total dissolved aluminum concentration after the addition of PAC-MC are shown in Figure 5. The $\mathrm{pH}$ of the experimental water decreased with the increase in the concentration of PAC-MC. The $\mathrm{pH}$ of the $0.2 \mathrm{~g} / \mathrm{L}$ and $0.5 \mathrm{~g} / \mathrm{L}$ groups changed little and gradually returned to the control group level with the passage of time. The results of the determination of total dissolved aluminum in water show that the greater the amount of PAC-MC used, the higher the aluminum content in the experimental water, but the increase in the aluminum content was not obvious in the low concentration groups, such as $0.2 \mathrm{~g} / \mathrm{L}$ and $0.5 \mathrm{~g} / \mathrm{L}$. In the determination of turbidity, it was found that the high-concentration PAC-MC group flocculated and precipitated readily in a certain period of time, but the change in turbidity was greater in the initial stage of addition.

The contents of $\mathrm{NO}_{2}{ }^{-}-\mathrm{N}$ and $\mathrm{NH}_{4}{ }^{-}-\mathrm{N}$ in the seawater of each group at the end (96 h) of the experiment are shown in Figure $5 \mathrm{~d}$. The addition of $0.2 \mathrm{~g} / \mathrm{L}$ and $0.5 \mathrm{~g} / \mathrm{L}$ PAC-MC effectively reduced the content of $\mathrm{NO}_{2}{ }^{-}-\mathrm{N}$ in seawater but had no significant effect on the content of $\mathrm{NH}_{4}^{+}-\mathrm{N}$. 

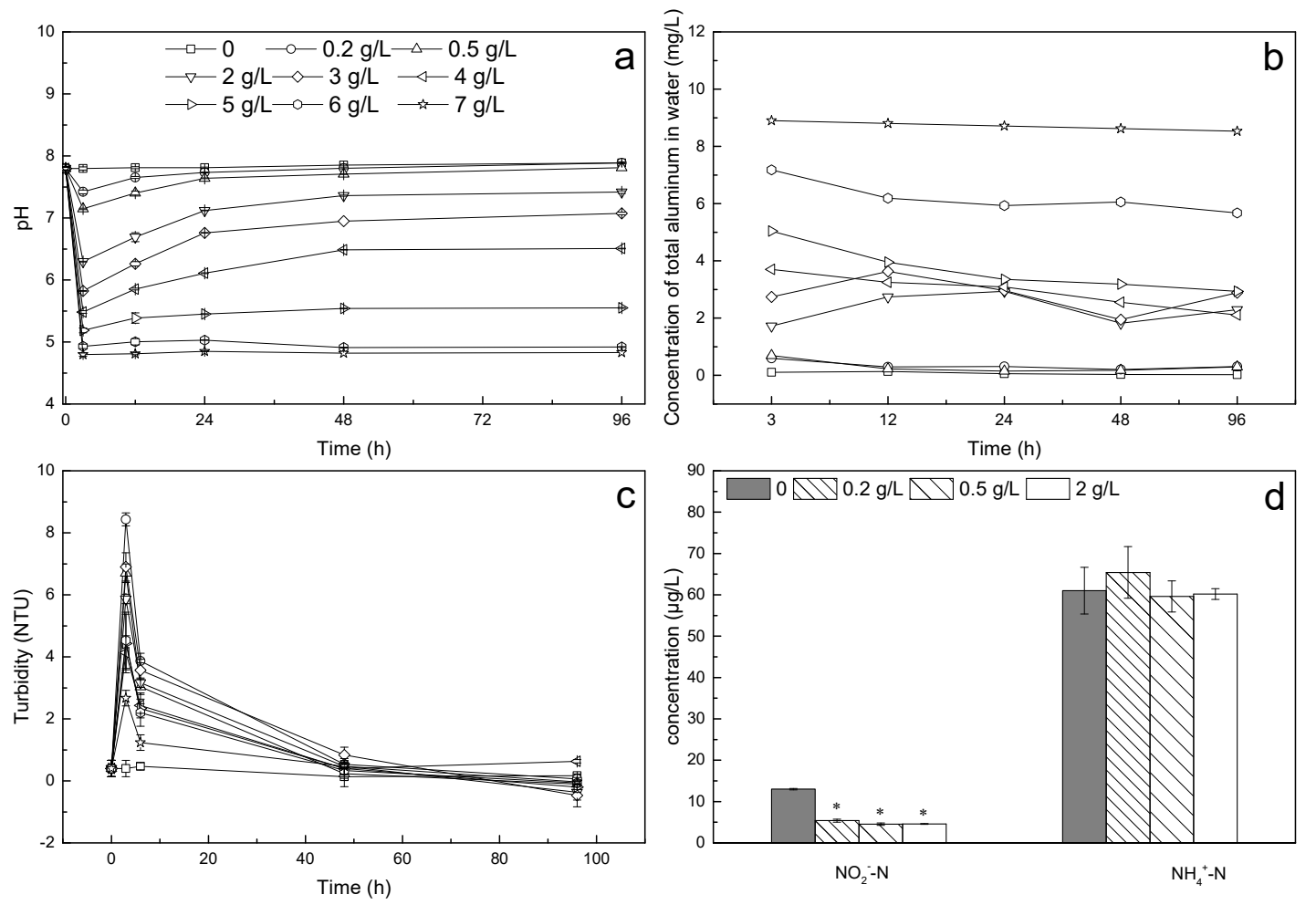

Figure 5. Changes in the water quality parameters with time after the addition of PAC-MC. (a-c) $\mathrm{pH}$, total aluminum content, and turbidity changes over time. (d) Contents of $\mathrm{NO}_{2}{ }^{-}-\mathrm{N}$ and $\mathrm{NH}_{4}{ }^{+}-\mathrm{N}$ in each group at $96 \mathrm{~h}$. Mean $\pm \mathrm{SD}$; ANOVA, Tukey; ${ }^{*}$ significant difference compared with control at $p<0.05$.

\subsection{Changes in the Aluminum Content in Newly Hatched Larvae}

In the experiment, the newly hatched larvae are tested within $12 \mathrm{~h}$ after hatching, which was the early stage of larvae before mouth opening. In the experiment, samples were collected before and after mouth opening to determine the aluminum content in the larvae, as shown in Figure 6. Before and after the mouth opening, there was no significant difference in the aluminum content in the larvae of each experimental group compared with the control group $(p>0.05)$.

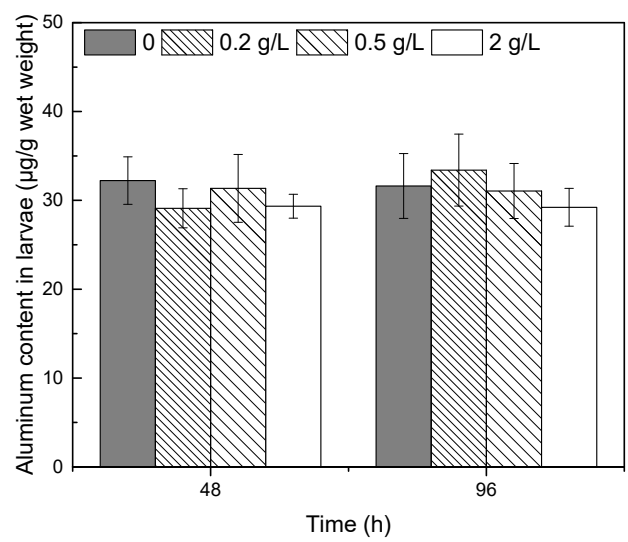

Figure 6. Changes in the aluminum content in larvae. Mean \pm SD; ANOVA, Tukey.

\subsection{Changes in Clay Properties before and after PAC Modification}

The median particle size of PAC-MC is $23.60 \mu \mathrm{m}$, and the median particle size of kaolin clay is $6.03 \mu \mathrm{m}$. After PAC modification, the clay particle size is significantly increased (Figure 7). 


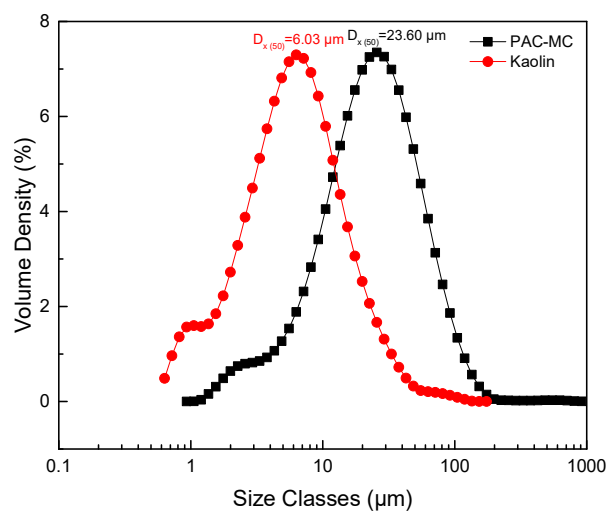

Figure 7. Particle size distribution of clay before and after PAC modification.

Kaolin clay has a lamellar structure. There are many finely divided small particles on the larger particles, the surface of the particles has cracks, the whole particles have sharp edges and corners, and the interface is clear. The surface of PAC-MC is covered by colloidal substances, and at the same time, particles with smaller diameters are attached to the outermost layer, making the entire clay particles thicker (Figure 8). It can also be seen from the figure that the particle size of PAC-MC is generally larger than that of kaolin clay.
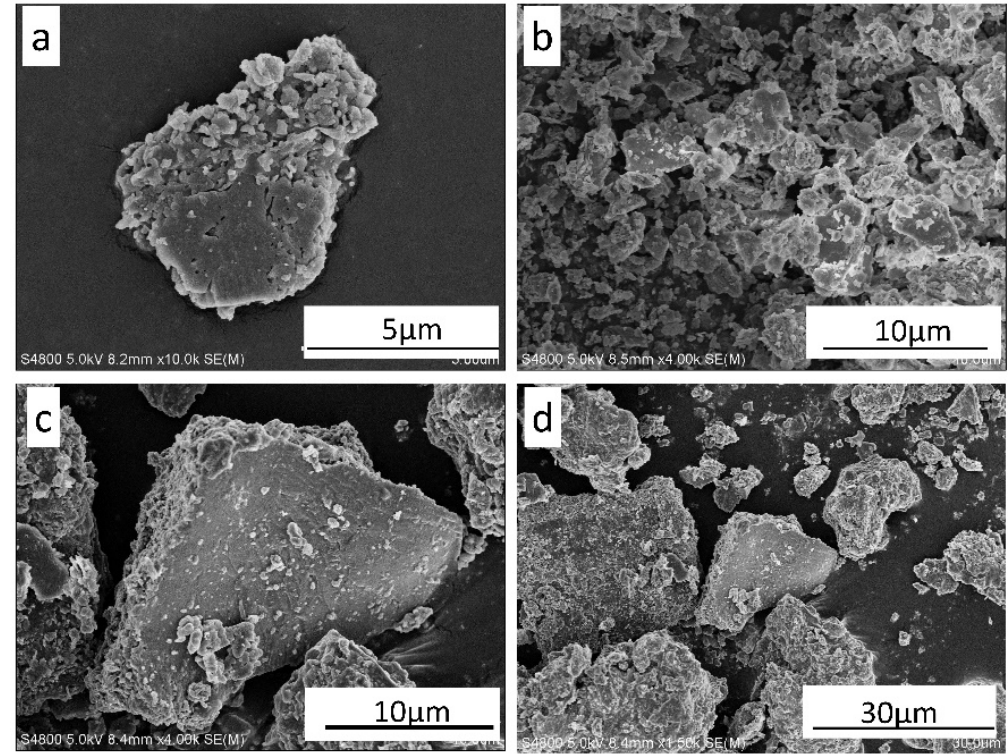

Figure 8. The SEM of kaolin clay and PAC-MC. Kaolin clay (a,b), PAC-MCB (c,d).

\section{Discussion}

\subsection{The Effect of PAC-MC on the Survival and Morphology of Marine Medaka}

Our results show that $96-\mathrm{h} \mathrm{LC}_{50}$ and SC of PAC-MC applied to marine medaka larvae were $5.204 \mathrm{~g} / \mathrm{L}$ and $1.94 \mathrm{~g} / \mathrm{L}$, respectively. According to the experience of spraying modified clay on site, the concentration of modified clay to treat harmful algal blooms is about $4-10 \mathrm{t} / \mathrm{km}^{2}$, the depth of the modified clay working area is generally $1-20 \mathrm{~m}$. Taking the minimum value of $1 \mathrm{~m}$ as an example, $4-10 \mathrm{t} / \mathrm{km}^{2}=(0.4-1) \times 10^{-2} \mathrm{~g} / \mathrm{L}$ is far less than 96-h $\mathrm{LC}_{50}$ and safe concentration. A low concentration of PAC-MC $(\leq 2 \mathrm{~g} / \mathrm{L})$ had no significant impact on the survival and morphology of the medaka larvae, but a small amount of modified clay particles attached to the surface of the larvae in the $2 \mathrm{~g} / \mathrm{L}$ group. A high concentration of PAC-MC (such as $7 \mathrm{~g} / \mathrm{L}$ ) would destroy the morphology of the larvae and cause larval death.

Previous studies have been conducted on the effect of different clays on typical marine fish. The experimental results are related to the type of clay used and the type of research 
object. For example, $75 \%$ to $100 \%$ survival was observed when juvenile and adult Chanos chanos, Lates calcalifer, and Siganus guttatus were exposed to ball clay, and the non-target organisms tested were not significantly affected by ball clay addition [20]. The LC 50 values of aminoclay in red sea bream (Pagrus major) and Japanese flounder (Paralichthys olivaceus) were $0.050 \%$ and $0.080 \%$, respectively, which are far higher than the recommended concentration of $0.001 \%(w / v)$ [14]. Low-concentration yellow clay $(\leq 0.23 \%, w / w)$ had no adverse effects on Korean rockfish (Sebastes schlegelii), but high concentrations of yellow clay $(1.16$ and $5.58 \%, w / w)$ may affect its respiratory metabolism [32].

There have been a few studies on the effect of PAC-MC on the early growth stage of non-target organisms. The 96-h $\mathrm{LC}_{50}$ values of PAC-MC applied to infant oysters (Crassostrea gigas, $\sim 0.2 \mathrm{~cm}$ ), infants of Patinopecten yessoensis, and juveniles of Apostichopus japonicas Selenka were $2.67 \mathrm{~g} / \mathrm{L}, 2.3 \mathrm{~g} / \mathrm{L}$, and $6.01 \mathrm{~g} / \mathrm{L}$, respectively [22,23,33]. Zhang Yue et al. studied the effect of different concentrations of PAC-MC on turbot embryos and found that the 24-h $\mathrm{LC}_{50}$ and $48-\mathrm{h} \mathrm{LC}_{50}$ values of PAC-MC applied to turbot embryos were $1.70 \mathrm{~g} / \mathrm{L}$ and $1.65 \mathrm{~g} / \mathrm{L}$, respectively, and the safe concentration was $0.5 \mathrm{~g} / \mathrm{L}$. A PACMC concentration equal to or smaller than $0.5 \mathrm{~g} / \mathrm{L}$ would not increase the deformity rate of newly hatched larvae [34]. The $\mathrm{LC}_{50}$ of PAC-MC applied to shellfish in the early developmental stage was slightly higher than that of marine medaka. Because turbot embryos are more sensitive than medaka larvae, their $\mathrm{LC}_{50}$ values and safe concentration are lower. The above research results have shown that within a certain concentration range, clay/MC has no significant effect on organisms.

During the spraying and flocculation of the modified clay, the flocs that form this way may adhere to or mechanically collide with the larvae, thus damaging the latter. Compared with kaolin, the median particle size of PAC-MC increases (Figure 7), and the sedimentation rate becomes faster. The median particle size $\mathrm{Dx}_{(50)}$ was $23.6 \mu \mathrm{m}$. The particles of PAC-MC are, thus, small, and as such, they are unlikely to cause mechanical damage to larvae due to their large size or heavy weight during spraying. According to previous research results, compared to natural clay, the thickness of floc clay layers of modified clay is larger [19]., the clay particles are more delicate and fluffy, and the surface of modified clay is soft, without obvious edges and corners, consistent with the SEM results of our experiment (Figure 8). It seems reasonable to hypothesize that fish would not be harmed by the process of flocculation. In the experiment, the PAC-MC was sprayed into seawater in the form of a suspension, and the flocculation process of the clay was rapid, which further slowed the mechanical impact of the clay particles on the larvae.

Compared with the $0.2 \mathrm{~g} / \mathrm{L}$ and $0.5 \mathrm{~g} / \mathrm{L}$ groups, the larvae of the $2 \mathrm{~g} / \mathrm{L}$ group had obvious clay particles attached to the surface of the fish at $96 \mathrm{~h}$ (Figure 2). It may be because the $2 \mathrm{~g} / \mathrm{L}$ PAC-MC group has more clay particles per unit of water and the sedimentation speed is slower. When the larvae stay in the suspension for a long time, the clay particles are more likely to adhere to the fins. If the concentration of PAC-MC is further increased, the size and number of clay particles might increase as much as to cause mechanical damage or adherence to the surface of the fish bodies, thus negatively affecting the external morphology of the larvae. Water quality parameters such as $\mathrm{pH}$ and turbidity might also change greatly, which would affect the physiological functions of the larvae and their survival. However, different from the static water experiment system in this study, in the field, with the flow of sea water, fish will not be in a high-concentration modified clay system for a long time. Additionally, the sea area on site is vast, fish can swim into the water that has completed flocculation to reduce the influence of modified clay. If the size of fish is relatively large, the mobility is stronger, the surface mucus is increased, the clay particles attach less easily, and the effect of modified clay on the external morphology of the fish will be lower. Therefore, spraying the appropriate concentration of PAC-MC will not cause obvious damage to the morphology of larger fish. In addition, the wide sea area has a stronger buffering capacity, and its $\mathrm{pH}$ and other environmental factors change less [35]. Therefore, the larvae in the field sea area may be less exposed to environmental stress than the laboratory system. 


\subsection{The Effect of PAC-MC on the Oxidative Stress of Marine Medaka}

When fish are subjected to environmental stress, they may produce ROS, which will cause oxidative damage. The production of ROS may induce changes in the activity of antioxidant enzymes to protect the body from oxidative damage. Previous studies have shown that the sediment suspension did not have fatal effects on Haliotis diversicolor in the short term, when suspended matter reached 300 or $400 \mathrm{mg} / \mathrm{L}$, the individual vitality of the abalone decreased obviously and the activity of SOD and CAT decreased significantly [36]. In the studies of Wang et al., the particles of sediment were $<75 \mu \mathrm{m}$ in size and continuously suspended for $96 \mathrm{~h}$ by aeration. This is different from the non-aerated conditions in this article, the particle size is also different, and the effect of antioxidant enzymes is also different. In this study, PAC-MC at low concentrations of $0.2 \mathrm{~g} / \mathrm{L}$ and $0.5 \mathrm{~g} / \mathrm{L}$ did not significantly affect the MDA content and the antioxidant enzyme activity. The $2 \mathrm{~g} / \mathrm{L}$ PACMC caused a significant increase in the content of ROS and MDA and the activity of the three antioxidant enzymes, which is consistent with previous research results. Zhang Yue et al. reported similar results when they studied the effect of PAC-MC on the antioxidant system of abalone [21]. The SOD-CAT system is the first line of defense against oxidative stress [37]. In the $2 \mathrm{~g} / \mathrm{L}$ group, the activities of antioxidant enzymes SOD and CAT increased rapidly to maintain the balance of ROS production and consumption in the body, so that the lipid peroxidation level first increased and then decreased.

Before the modified clay is completely flocculated, it will exist in the water as suspended matter. Previous studies have found that, due to the existence of a certain background value of suspended solids in natural seawater, most marine fish have a strong tolerance to low-dose suspended solids, and $300-400 \mathrm{mg} / \mathrm{L}$ of suspended sediment suspension from the shrimp farming pond significantly reduced the SOD and CAT enzyme activities of Haliotis diversicolor compared with the control after $24 \mathrm{~h}$ [36]. Under the stress of $5000 \mathrm{mg} / \mathrm{L}$ and 10,000 mg/L of suspended solids, T-SOD enzyme activity in juvenile Paralichthys olivaceus showed a trend of first increased, then decreased, and then increased again, and CAT enzyme activity showed an initial increase and then a decrease [38]. In the abovementioned study, the suspended matter was always in a suspended state, and the concentration of the suspended matter was significantly greater than the PAC-MC concentration used in the herein experiment. Therefore, the suspension environment caused by PAC-MC in the current study is unlikely to have significant adverse impacts on larval fish.

Studies suggest that the physiological effects induced by changes in environmental stress factors (such as water $\mathrm{pH}$, temperature, salinity, etc.) may be achieved through redox pathways [39-41], that is, environmental stress factors cause abnormal aerobic metabolism in organisms and a large amount of reactive oxygen-free radicals. Accumulation causes oxidative damage to the body. High $\mathrm{pH}$ stress significantly increases the content of active oxygen free radicals in marine scallops (Chattonella marina) and Chlamys farreri [42,43], and high and low $\mathrm{pH}$ stresses both reduce Anodonta woodiana Lea antioxidant enzyme activity [44]. In this study, the $\mathrm{pH}$ of the $0.2 \mathrm{~g} / \mathrm{L}$ and $0.5 \mathrm{~g} / \mathrm{L}$ PAC-MC groups did not change significantly compared with the control group. The $\mathrm{pH}$ of the $2 \mathrm{~g} / \mathrm{L}$ group was lower than 7 within $24 \mathrm{~h}$, which reflects a stressed state. This may be one of the causes of oxidative stress in larvae.

\subsection{Effects of PAC-MC on Aluminum Accumulation in Fish}

Previous studies have shown that the content of ionic aluminum in water is higher than $0.2-0.5 \mathrm{mg} / \mathrm{L}$, which can kill salmon [45]. The PAC-MC used in this study was made by adding a PAC modifier to kaolin clay. Therefore, this experiment also focused on the effect of aluminum on larvae. The results showed that PAC-MC $\leq 2 \mathrm{~g} / \mathrm{L}$ had no significant effect on the aluminum content of the marine medaka. Wang et al. [33] found that 0.1, 0.5, and $1.0 \mathrm{~g} / \mathrm{L}$ PAC-MC had no effect on the aluminum content in tissues of Apostichopus japonicas Selenka, which is consistent with the results of our study.

The total amount and the form of aluminum are both important factors that affect aluminum toxicity. In this study, the total aluminum content in the experimental water 
column of the $0.2 \mathrm{~g} / \mathrm{L}$ and $0.5 \mathrm{~g} / \mathrm{L}$ PAC-MC groups did not change significantly after $3 \mathrm{~h}$ $(p>0.05)$; that of the $2 \mathrm{~g} / \mathrm{L}$ group increased significantly $(p<0.05)$ (Figure $5 \mathrm{~b})$, and none of them had a significant impact on the survival and the aluminum content of larvae. The concentration of modifier PAC in $0.2 \mathrm{~g} / \mathrm{L}$ and $0.5 \mathrm{~g} / \mathrm{L} \mathrm{PAC-MC} \mathrm{is} 0.04 \mathrm{~g} / \mathrm{L}$ and $0.1 \mathrm{~g} / \mathrm{L}$, respectively, which has limited influence on the total aluminum content in the water. The concentration of modifier PAC in the $2 \mathrm{~g} / \mathrm{L}$ group increased, but the toxicity was limited. The form of aluminum is an important factor considering the toxicity of this element in the environment and biological systems. Toxicity experiments on organisms proves that inorganic mononuclear aluminum is the most toxic form [46]. In a PAC system, $\mathrm{pH}$ has a significant effect on the speciation transformation of PAC. Mononuclear aluminum is one of the most unstable primary flocculants and can be rapidly transformed into other forms according to the reaction conditions. In the range of $\mathrm{pH} 6-8$, the proportion of mononuclear aluminum in a PAC system is very low [47]. In this experiment, the seawater $\mathrm{pH}$ levels of the control, $0.2,0.5$, and $2 \mathrm{~g} / \mathrm{L}$ groups were all within the abovementioned range (Figure 5a). Scholars have tracked the changes in concentration of mononuclear aluminum in different PAC-MC concentration systems and found that the mononuclear aluminum generally decreased over time. For example, mononuclear aluminum in PAC-MC with a concentration $\leq 0.25 \mathrm{~g} / \mathrm{L}$ would rapidly decrease to below the safe concentration within one day, without a lasting impact on the water column [48]. The aluminum content in the larvae was measured before and after the larval mouth-opening period to eliminate the influence of larval mouth opening on aluminum intake. At $48 \mathrm{~h}$, there was no significant difference between the experimental groups $(p>0.05)$, and the same was true at $96 \mathrm{~h}$. The experimental results show that the aluminum content introduced by the modified clay at the experimental concentration had a negligible effect on the experimental larvae.

\section{Conclusions}

This article studied the effect of PAC-MC on the model organism for marine ecotoxicology -the marine medaka. The results show that the $96-\mathrm{h} \mathrm{LC} 50$ of PAC-MC for newly hatched medaka larvae was $5.204 \mathrm{~g} / \mathrm{L}$, which was much higher than the concentration used on-site (4-10 t/ $\left./ \mathrm{km}^{2}\right)$. The effective dosage of PAC-MC at the site had no significant effect on the survival, growth, morphology, antioxidant system, and aluminum content of newly hatched marine medaka larvae. A concentration of $2 \mathrm{~g} / \mathrm{L}$ PAC modified clay will cause oxidative damage to larvae and will increase the activity of antioxidant enzymes. Higher concentrations ( $>2 \mathrm{~g} / \mathrm{L}$ ) of modified clay will cause the larvae to die. Through experiments with newly hatched marine medaka larvae, we believe that the application of a suitable concentration of modified clay at a harmful algal bloom treatment site will not have an adverse effect on fish.

Supplementary Materials: The following are available online at https://www.mdpi.com/article/ 10.3390/jmse9080822/s1, Figure S1. XRD patterns of Kaolin., Table S1. The mineral composition of kaolin., Table S2. Proportion of different elements in kaolin, Figure S2. The effect of PAC-MC on the total length of newly hatched marine, Figure S3. Picture used to measure fluorescence intensity, Table S3. Fluorescence intensity analysis result by one-way ANOVA, Table S4. Post Hoc Tests-Multiple comparisons. References $[49,50]$ are cited in the supplementary materials.

Author Contributions: Conceptualization, P.Z. and X.S.; investigation, methodology, and validation, P.Z., X.D., and H.S.; formal analysis and visualization, P.Z. and J.L.; resources and data curation, P.Z. and Y.Z.; writing—original draft preparation, P.Z.; writing—review and editing, P.Z., X.S., and Z.Y.; supervision, project administration, and funding acquisition, X.S. and Y.Z. All authors have read and agreed to the published version of the manuscript.

Funding: This research was funded by National Natural Science Foundation of China (No. 41976148), the Key R\&D project of Shandong Province (2019JZZ010808), the Taishan Scholars Climbing Program of Shandong Province of 2019. 
Institutional Review Board Statement: The study was conducted according to the guidelines of the Declaration of Helsinki, and approved by Institutional Animal Care and Use Committee of the Institute of Oceanology, Chinese Academy of Sciences. (protocol code: KLMEES202103, date of approval: 2021.03.01).

Informed Consent Statement: Not applicable.

Data Availability Statement: Data are available upon request; please contact the contributing authors.

Conflicts of Interest: The authors declare no conflict of interest.

\section{References}

1. León-Muñoz, J.; Urbina, M.A.; Garreaud, R.; Iriarte, J.L. Hydroclimatic conditions trigger record harmful algal bloom in western Patagonia (summer 2016). Sci. Rep. 2018, 8, 1330. [CrossRef]

2. Shirota, A. Red tide problem and countermeasures (2). Int. J. Fish. Technol. 1989, 1, 195-223.

3. Kim, H.G. Mitigation and controls of HABs. Ecol. Harmful Algae 2006, 189, 327-338. [CrossRef]

4. Chen, W.; Jia, Y.; Li, E.; Shuang, Z.; Zhou, Q.; Liu, L.; Song, L. Soil-Based Treatments of Mechanically Collected Cyanobacterial Blooms from Lake Taihu: Efficiencies and Potential Risks. Environ. Technol. 2012, 46, 13370-13376. [CrossRef] [PubMed]

5. Zhang, Y.; Fu, Q. Algal fouling of microfiltration and ultrafiltration membranes and control strategies: A review. Sep. Purif. Technol. 2018, 203, 193-208. [CrossRef]

6. Divakaran, R.; Pillai, V. Flocculation of algae using chitosan. J. Appl. Phycol. 2002, 14, 419-422. [CrossRef]

7. Sun, X.X.; Lee, Y.J.; Choi, J.K.; Kim, E.K. Synergistic effect of sophorolipid and loess combination in harmful algal blooms mitigation. Mar. Pollut. Bull. 2004, 48, 863-872. [CrossRef]

8. Ma, J.; Wei, L. Effectiveness and mechanism of potassium ferrate(VI) preoxidation for algae removal by coagulation. Water Res. 2002, 36, 871-878. [CrossRef]

9. Zhang, S.D.; Song, X.X.; Cao, X.H.; Ming, Y.Z. Inhibitory Effect of Gracilaria lemaneiformis(Bory) Weber Bosse on the Cocultured Scrippsiella trochoidea(Stein) Loeblich III Under Controlled Laboratory Conditions. Environ. Sci. 2008, 29, $2291-2295$.

10. Marcoval, M.A.; Pan, J.; Tang, Y.; Gobler, C.J. The ability of the branchiopod, Artemia salina, to graze upon harmful algal blooms caused by Alexandrium fundyense, Aureococcus anophagefferens, and Cochlodinium polykrikoides. Estuar. Coast. Shelf Sci. 2013, 131, 235-244. [CrossRef]

11. Kodama, M.; Doucette, G.J.; Green, D.H. Relationships between bacteria and harmful algae. Ecol. Harmful Algae 2006, 189, 243-255.

12. Yang, Y.F.; Liu, Q.; Chai, Z.Y.; Tang, Y.Z. Inhibition of marine coastal bloom-forming phytoplankton by commercially cultivated Gracilaria lemaneiformis (Rhodophyta). J. Appl. Phycol. 2015, 27, 2341-2352. [CrossRef]

13. Ichiro, I.; Mineo, Y.; Yutaka, H. Eutrophication and occurrences of harmful algal blooms in the Seto Inland Sea, Japan. Plankton Benthos Res. 2006, 1, 71-84.

14. Lee, Y.C.; Jin, E.S.; Jung, S.W.; Kim, Y.M.; Chang, K.S.; Yang, J.W.; Kim, S.W.; Kim, Y.O.; Shin, H.J. Utilizing the algicidal activity of aminoclay as a practical treatment for toxic red tides. Sci. Rep. 2013, 3, 1292. [CrossRef]

15. Yu, Z.; Zou, J. A more effective clay for removing red tide organisms. J. Nat. Disasters 1994, 3, $105-109$.

16. Yu, Z.; Zou, J.; Ma, X. A new method to improve the capability of clays for removing red tide organisms. Oceanol. Et Limnol. Sin. 1994, 25, 226-232.

17. Yu, Z.M.; Zou, J.Z.; Ma, X.N. Application of clays to removal of red tide organisms I. Coagulation of red tide organisms with clays. Chin. J. Oceanol. Limnol. 1994, 12, 316-324.

18. Yu, Z.M.; Zou, J.Z.; Ma, X.N. Application of clays to removal of red tide organisms II. Coagulation of different species of red tide organisms with montmorillonite and effect of clay pretreatment. Chin. J. Oceanol. Limnol. 1994, 12, 316-324.

19. Yu, Z.; Song, X.; Cao, X.; Liu, Y. Mitigation of harmful algal blooms using modified clays: Theory, mechanisms, and applications. Harmful Algae 2017, 69, 48-64. [CrossRef]

20. Orizar, I.S.; Rivera, P.P.L.; San Diego-McGlone, M.L.; Azanza, R.V. Harmful Algal Bloom (HAB) mitigation using ball clay: Effect on non-target organisms. J. Environ. Sci. Manag. 2013, 16, 36-43.

21. Zhang, Y.; Song, X.; Shen, H.; Cao, X.; Yuan, Y.; Wu, Z.; Yu, Z. The Effects of Modified Clay on Abalone (Haliotis discus hannai) Based on Laboratory and Field Experiments. Environ. Toxicol. Chem. 2020, 39, 2065-2075. [CrossRef]

22. Wang, Z.; Yu, Z.; Song, X.; Cao, X. Effects of modified clay on the infant of Patinopecten yessoensis for HABs control. Mar. Environ. Sci. 2014, 33, 817-821.

23. Gao, Y.; Yu, Z.; Song, X.; Cao, X. Impact of Modified Clays on the Infant Oyster(Crassostrea gigas). Mar. Sci. Bull. 2007, 26, 53-60.

24. Wang, Z.; Song, X.; Zhang, Y.; Yu, Z.; Tang, X. Effects of modified clay on Mercenaria mercenaria. Oceanol. Limnol. Sin. 2019, 50, 692-699.

25. Kim, B.M.; Kim, J.; Choi, I.Y.; Raisuddin, S.; Au, D.; Leung, K.; Wu, R.; Rhee, J.S.; Lee, J.S. Omics of the marine medaka (Oryzias melastigma) and its relevance to marine environmental research. Mar. Environ. Res. 2016, 113, 141-152. [CrossRef] [PubMed] 
26. Smith, R.W. Relations Among Equilibrium and Nonequilibrium Aqueous Species of Aluminum Hydroxy Complexes. In Nonequilibrium Systems in Natural Water Chemistry; American Chemical Society: Washington, WA, USA, 1971; Volume 106, pp. 250-279.

27. Bersillon, J.; Hsu, L.; Pa, H.; Fiessinger, F. Characterization of Hydroxy-Aluminum Solutions. Soil Sci. Soc. Am. J. 1980, 44, 630-634. [CrossRef]

28. Winston, G.W.; Giulio, R. Prooxidant and antioxidant mechanisms in aquatic organisms. Aquat. Toxicol. 1991, 19, 137-161. [CrossRef]

29. Stegeman, J.J.; Brouwer, M.; Giulio, R.; Frlin, L.; Veld, P. Molecular responses to environmental contamination Enzyme and protein systems as indicators of chemical exposure and effect. Biomark. Biochem. Physiol. Histol. Mark. Anthropog. Stress 1992, 235-335.

30. Van der Oost, R.; Beyer, J.; Vermeulen, N.P.E. Fish bioaccumulation and biomarkers in environmental risk assessment: A review. Environ. Toxicol. Pharmacol. 2003, 13, 57-149. [CrossRef]

31. Wang, X.Q. Effects of dimethylhydantoin and carbohydrate on growth and immunity of Litopenaeus vannamei. Adv. Mater. Res. 2012, 356-360, 146-151.

32. Lee, C.K.; Kim, W.S.; Park, Y.T.; Jo, Q.T. Effect of Yellow Clay on the Oxygen Consumption Rate of Korean rockfish, Sebastes schlegelii. J. Korean Soc. Mar. Environ. Saf. 2013, 19, 241-247. [CrossRef]

33. Wang, Z.; Yu, Z.; Song, X.; Cao, X.; Liu, K. Impact of modified clay on the growth of the infant Apostichopus japonicas Selenka in HABs controling. Oceanol. Limnol. Sin. 2014, 45, 233-238.

34. Zhang, Y.; Song, X.; Yu, Z.; Zhang, P.; Cao, X.; Yuan, Y. Impact assessment of modified clay on embryo-larval stages of turbot Scophthalmus maximus L. Chin. J. Oceanol. Limnol. 2019, 037, 1051-1061. [CrossRef]

35. Cao, X.H.; Yu, Z.-M.; Qiu, L.X. Field experiment and emergent application of modified clays for phaeocystis globosa blooms mitigation. Oceanol. Limnol. Sin. 2017, 48, 753-759.

36. Wang, G.; Xie, J.; Yu, D.-G.; Wu, L.; Hu, Z.-Y. Physiological responses of abalone Haliotis divericolor to suspended sediment stress. J. Dalian Fish. Univ. 2007, 22, 352-356.

37. Yuan, J.; Wang, X.; Gu, Z.; Zhang, Y.; Wang, Z. Activity and Transcriptional Responses of Hepatopancreatic Biotransformation and Antioxidant Enzymes in the Oriental River Prawn Macrobrachium nipponense Exposed to Microcystin-LR. Toxins 2015, 7, 4006-4022. [CrossRef]

38. Xiao, G.; Xu, W.; Jia, L.; Zheng, D.; Zhang, B.; Ma, C. Effects of Suspended Substances on Antioxidant Enzyme Activities in Muscle of Paralichthys olivaceus and Related Gene Expressions. Adv. Mar. Sci. 2016, 34, 542-552.

39. Ryter, S.W.; Kim, H.P.; Hoetzel, A.; Park, J.W.; Nakahira, K.; Wang, X.; Choi, A.M. Mechanisms of Cell Death in Oxidative Stress. Antioxid. Redox Signal. 2007, 9, 49-89. [CrossRef]

40. Assefa, Z.; An, V.L.; Garmyn, M.; Agostinis, P. Ultraviolet radiation-induced apoptosis in keratinocytes: On the role of cytosolic factors. Biochim. Biophys. Acta 2005, 1755, 90-106. [CrossRef] [PubMed]

41. Richier, S.; Sabourault, C.; Courtiade, J.; Zucchini, N.; Allemand, D.; Furla, P. Oxidative stress and apoptotic events during thermal stress in the symbiotic sea anemone, Anemonia viridis. FEBS J. 2010, 273, 4186-4198. [CrossRef] [PubMed]

42. Liu, W.; Au, D.W.T.; Anderson, D.M.; Lam, P.K.S.; Wu, R.S.S. Effects of nutrients, salinity, pH and light:dark cycle on the production of reactive oxygen species in the alga Chattonella marina. J. Exp. Mar. Biol. Ecol. 2007, 346, 76-86. [CrossRef]

43. Fan, Z.; Yang, A.; Liu, Z.; Dai, J.; Dong, Y.; Ren, J. Effect of pH on the immune factors of Chlamys farreri. J. Fish. Sci. China 2006, 13, 650-654.

44. Wen, C.; Zhang, L.; Hu, B.; Rao, Y.; Chen, S.; Wang, F. Effect of pH on the Five Immune Factors of Anodonta Woodiana. J. Nanchang Univ. (Nat. Sci.) 2009, 33, 172-176.

45. Cornwell, D.A.; Burmaster, J.W.; Francis, J.L.; Friedline, J.C.J.; Houck, C.; King, P.H.; San Giacomo, R. Committee report: Research needs for alum sludge discharge. J. Am. Water Work. Assoc. 1987, 79, 99-104.

46. Yang, X.; Zhang, F.; Wang, X.; Gan, N.; Zou, G.; Bi, S. Novel Analytical Techniques for Fractionation and Speciation of Aluminum(III) in Environmental and Biological Systems. Chin. J. Anal. Chem. 2003, 31, 1131-1138.

47. Yan, M.; Wang, D.; Yu, J.; Ni, J.; Edwards, M.; Qu, J. Enhanced coagulation with polyaluminum chlorides: Role of pH/Alkalinity and speciation. Chemosphere 2008, 71, 1665-1673. [CrossRef]

48. Dong, X.; Cao, X.; Jiang, W.; Song, X.; Yu, Z. Profiles of and variations in aluminum species in PAC-MC used for the removal of blooming microalgae. J. Environ. Sci. 2021, 106, 76-82. [CrossRef]

49. Zhang, J.; Wan, S.; Clift, P.D.; Huang, J.; Yu, Z.; Zhang, K.; Mei, X.; Liu, J.; Han, Z.; Nan, Q.; et al. History of Yellow River and Yangtze River delivering sediment to the Yellow Sea since 3.5Ma: Tectonic or climate forcing? Quat. Sci. Rev. 2019, 216, 74-88. [CrossRef]

50. Wan, S.; Li, A.; Clift, P.D.; Stuur, J.-B.W. Development of the East Asian monsoon: Mineralogical and sedimentologic records in the South China Sea since 20 Ma. Palaeogeogr. Palaeoclimatol. Palaeoecol. 2007, 254, 561-582. [CrossRef] 